\title{
Lokale verkiezingen: een lokaal of nationaal feest der democratie?
}

\author{
Eefje Steenvoorden, Babs Broekema \& Jeroen van der Waal
}

\begin{abstract}
De term 'tweedeordeverkiezing' geeft aan dat sommige verkiezingen van minder groot belang zijn voor burgers dan nationale verkiezingen. Dit artikel gaat na in hoeverre dat geldt voor de Nederlandse gemeenteraadsverkiezingen. Het bouwt voort op de literatuur over het tweedeordekarakter van lokale verkiezingen in Nederland. De auteurs richten zich op de vraag in hoeverre Nederlandse gemeenteraadsverkiezingen tweedeordeverkiezingen zijn door het stemmen bij de lokale en nationale verkiezingen op verschillende manieren met elkaar te vergelijken. Ze vergelijken vier aspecten van lokaal en nationaal stemmen: de opkomst, de achterliggende factoren die opkomst verklaren, de factoren die een stem voor lokale partijen verklaren, en het nationale of lokale karakter van stemmotieven bij de gemeenteraadsverkiezingen in 2014. De resultaten geven geen eenduidig antwoord op de vraag in hoeverre gemeenteraadsverkiezingen lokaal georiënteerd zijn. De vier verschillende invalshoeken leveren allemaal dubbelzinnige patronen op. Gemeenteraadsverkiezingen hebben dus inderdaad deels een tweedeordekarakter, zoals eerder betoogd en getoond. Toch mogen we de lokale affiniteit en politieke betrokkenheid ook niet onderschatten. Dat een deel van de burgers zich wel interesseert in de lokale politiek, in lokale partijen en in verkiezingsprogramma's van lokale afdelingen wijst wel degelijk op een lokale politieke dynamiek.
\end{abstract}

\section{$1 \quad$ Inleiding}

Dat lokale verkiezingen een andere dynamiek kennen dan nationale verkiezingen is een bekend gegeven. De term 'tweedeordeverkiezing' is al bijna vier decennia geleden (Reif \& Schmitt, 1980) gemunt om aan te geven dat sommige verkiezingen van minder groot belang zijn voor burgers dan nationale verkiezingen, zoals die voor de Tweede Kamer. De kiezer heeft bij tweedeordeverkiezingen het idee dat er minder op het spel staat en laat zich vooral leiden door wat er speelt in de nationale politiek, zo is de gedachte.

In dit artikel gaan we na in hoeverre dat geldt voor de Nederlandse gemeenteraadsverkiezingen. Het meeste onderzoek naar deze veronderstelde hiërarchie tussen verkiezingen richt zich op Europese verkiezingen (o.a. Van der Eijk e.a., 1996; Carruba \& Timpone, 2005; Hix \& Marsh, 2007; Marsh \& Mikhaylov, 2010). Deze studies bevestigen het tweedeordekarakter van deze verkiezingen. Zo is de opkomst lager dan bij nationale verkiezingen, lijkt er voor kiezers 'minder op het spel te staan' dan bij nationale verkiezingen en spelen nationale motieven een rol bij het uitbrengen van een stem. 
Het aantal studies dat zich expliciet richt op lokale verkiezingen is - met name in Nederland - kleiner, en toont minder consensus over het tweedeordekarakter ervan. Enerzijds wijzen bevindingen uit dat nationale motieven en ontwikkelingen een duidelijke rol spelen bij lokale verkiezingen (Van der Kolk, 1997; Lelieveldt \& Van der Does, 2014) en dat lokale thema's er weinig toe doen (Boogers \& Van Ostaaijen, 2011). Bovendien vinden Boogers en Salome (2014: 26) dat bij de gemeenteraadsverkiezingen van 2014 'in alle gemeenten dezelfde partijen winnen en verliezen, ongeacht de samenstelling van het bestuur of het gevoerde beleid'. Dit suggereert dat lokale politieke ontwikkelingen nauwelijks een rol spelen bij lokaal stemgedrag. Anderzijds stellen verschillende auteurs dat lokale verkiezingen in mindere mate een tweedeordekarakter hebben dan soms gedacht. Zo stellen Heath e.a. (1999) op basis van hun vergelijking tussen lokale en Europese verkiezingen in Groot-Brittannië dat de eerste in mindere mate tweedeordeverkiezingen zijn, op basis van opkomst en de invloed van lokale context op stemmotieven. Ook Marien e.a. (2015) vinden een duidelijke rol voor lokaal geïnspireerde motieven bij lokale verkiezingen, al stemt de grote meerderheid (75\%) op dezelfde partij als bij de nationale verkiezingen.

In dit artikel bouwen we voort op de literatuur over het tweedeordekarakter van lokale verkiezingen in Nederland. We richten ons op de vraag in hoeverre Nederlandse gemeenteraadsverkiezingen tweedeordeverkiezingen zijn door het stemmen bij de lokale en nationale verkiezingen op verschillende manieren met elkaar te vergelijken. Deze vergelijking is vooralsnog weinig gemaakt, met de uitzondering van Rallings en Thrasher (2007), die vinden dat met name lokale betrokkenheid en belangen van invloed zijn op lokaal stemmen.

We vergelijken vier aspecten van lokaal en nationaal stemmen: de opkomst, de achterliggende factoren die opkomst verklaren, de factoren die een stem voor lokale partijen verklaren, en het nationale of lokale karakter van stemmotieven bij de gemeenteraadsverkiezingen 2014. De vraag die bij elke van de vier vergelijkingen aan bod komt, is hoe groot de invloed is van lokale versus nationale factoren. Immers, invloed van lokale factoren spreekt een tweedeordekarakter tegen, terwijl invloed van nationale factoren het onderschrijft. In de conclusie komen we terug op de uitkomsten van deze vergelijkingen en beantwoorden we de vraag in hoeverre de Nederlandse gemeenteraadsverkiezingen als tweedeordeverkiezingen kunnen worden bestempeld.

\section{Opkomst bij gemeenteraadsverkiezingen 2014 en Tweede Kamerverkiezingen 2012}

Een bekende bevinding bij onderzoek naar verkiezingsopkomst is dat deze lager is bij tweedeordeverkiezingen (Reif \& Schmitt, 1980; Boogers e.a., 2010; Lelieveldt \& Van der Does, 2014). Figuur 1 toont de opkomst bij verschillende verkiezingen in Nederland sinds de jaren zestig van de vorige eeuw. We zien dat bij de gemeenteraadsverkiezingen van 2014 met 54\% aanzienlijk minder kiezers een stem uitbrachten dan bij de Tweede Kamerverkiezingen van 2012, waar de opkomst op 


\section{Figuur 1 Opkomst bij verkiezingen in Nederland}

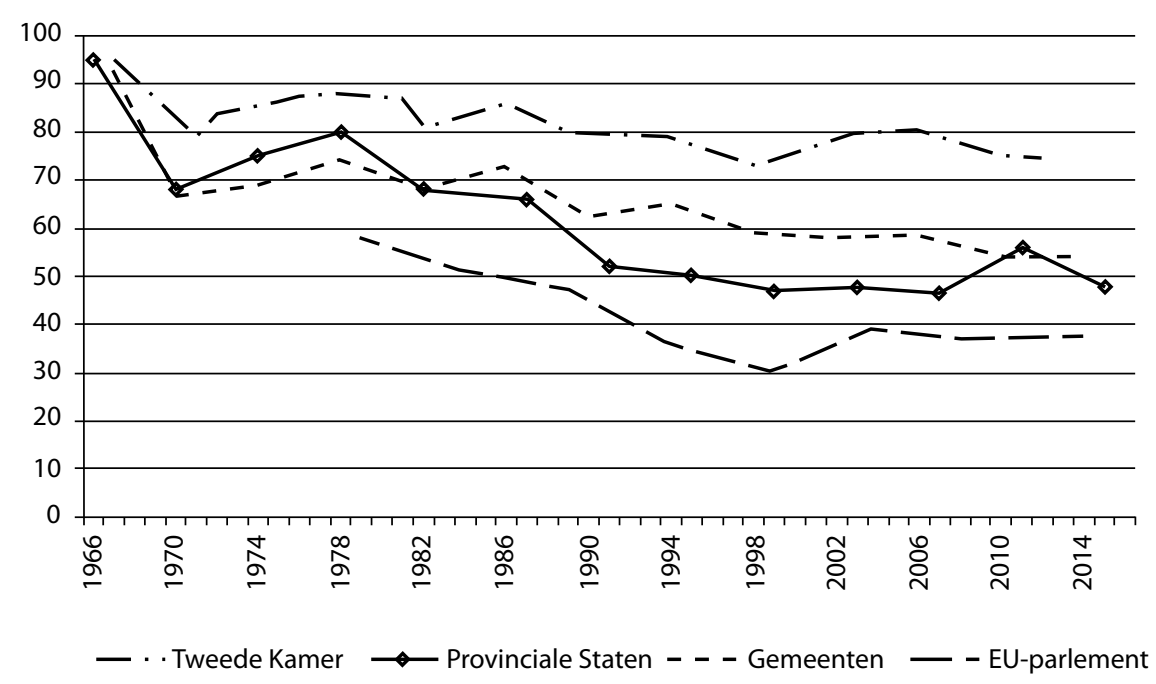

Bron: databank verkiezingsuitslagen Kiesraad: www.verkiezingsuitslagen.nl.

75\% lag. Dit verschil in opkomst tussen deze twee typen verkiezingen is geen typisch Nederlands verschijnsel, maar zien we in veel westerse landen (Heath e.a., 1999; Ervik, 2012; Marien e.a., 2015). En 2014 is geen uitzonderlijk jaar, het opkomstpercentage bij de gemeenteraadsverkiezingen ligt sinds 1998 onder de $60 \%$. Bovendien is de opkomst over de hele linie gedaald, maar bij nationale verkiezingen wel duidelijk in mindere mate dan zogenaamde tweedeordeverkiezingen. Bovendien, en in lijn met onderzoek in andere Europese landen (Hix \& Marsh, 2007; Franklin \& Hobolt, 2011), is de opkomst bij de Europese verkiezingen het laagst. Op basis van deze patronen lijken lokale verkiezingen weliswaar van minder belang in de ogen van burgers dan nationale verkiezingen, maar niet in dezelfde mate als Europese verkiezingen.

\section{Stemgedrag bij nationale en lokale verkiezingen vergeleken}

Als tweede stap om het tweedeordekarakter van lokale verkiezingen in Nederland te achterhalen kijken we naar de achterliggende factoren die bepalen of burgers nationaal en/of lokaal gaan stemmen. We kunnen daarmee nagaan hoe lokaal geïnspireerd verkiezingen zijn. Maar we kijken ook in bredere zin welke factoren bepalen of mensen gaan stemmen bij lokale verkiezingen, en of die wezenlijk verschillen van stemgedrag bij nationale verkiezingen. Dit doen we aan de hand van vragen in het LKO 2016 over het stemgedrag in de Tweede Kamerverkiezingen 
Tabel 1 Percentage kiezers naar stemgedrag in gemeentelijke (2014) en landelijke (2012) verkiezingen

\begin{tabular}{llll}
\hline & & \multicolumn{2}{l}{ Landelijk (20 I 2) } \\
& & Nee & Ja \\
\hline Gemeentelijk (20 I 4) & Nee & $23(N S)$ & $22(T K)$ \\
& Ja & $2(G R)$ & 53 (beide) \\
\hline
\end{tabular}

2012 en de gemeenteraadsverkiezingen 2014. Tabel A in de bijlage toont hoe de variabelen in alle analyses precies zijn gemeten.

Allereerst willen we inzicht verkrijgen in wie bij zowel de Tweede Kamerverkiezingen als de gemeenteraadsverkiezingen heeft gestemd, wie slechts bij een van de verkiezingen stemde, of helemaal niet. Is het zo dat sommige burgers alleen lokaal stemmen en andere alleen nationaal? Dat zou wijzen op een duidelijk andere, maar wel eigen lokale politieke dynamiek. Dit blijkt op basis van tabel 1 niet het geval. Van alle burgers heeft de grootste groep (53\%) bij beide verkiezingen gestemd. Ook een andere groep was consistent: 23\% bleef beide keren thuis. Een selectieve deelname zien we vooral bij de Tweede Kamerverkiezingen: 22\% kwam alleen toen naar de stembus. Omgekeerd komt lokaal stemmen nauwelijks voor: dit geldt slechts voor $2 \%$ van de respondenten. Tabel 1 lijkt erop te duiden dat gemeenteraadsverkiezingen nauwelijks burgers activeren die bij de nationale verkiezingen thuisblijven.

Vervolgens gaan we in op de vraag welke karakteristieken de twee groepen kiezers onderscheiden - (1) burgers die zowel lokaal als nationaal stemmen en (2) burgers die alleen nationaal stemmen - van zowel niet-stemmers als elkaar. De meeste onderzoeken naar lokaal stemgedrag focussen alleen op het stemmen bij lokale verkiezingen, waardoor er nog weinig inzicht is in wat nationaal en lokaal stemmen van elkaar onderscheid.

We maken drie vergelijkingen, namelijk (1) tussen niet-stemmers (NS) en alleen nationale stemmers (TK), (2) tussen NS en stemmers bij lokale en nationale verkiezingen (beide), en (3) tussen de twee groepen kiezers onderling (TK en beide). We kijken naar drie typen karakteristieken, waarvan uit de literatuur bekend is dat ze invloed hebben op het uitbrengen van een stem bij verkiezingen: sociaaldemografische kenmerken, burgerschapszin en politieke betrokkenheid. 

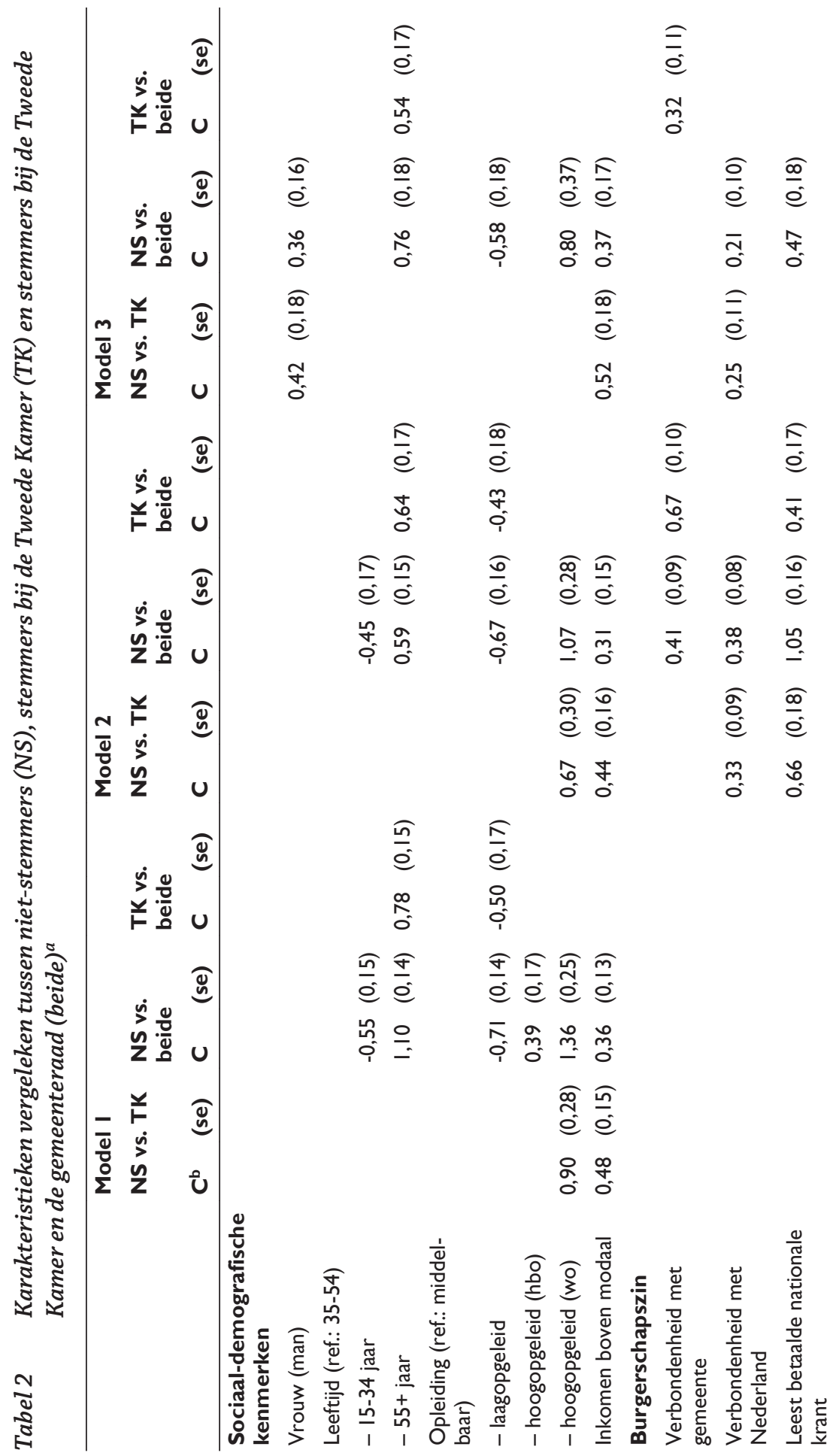


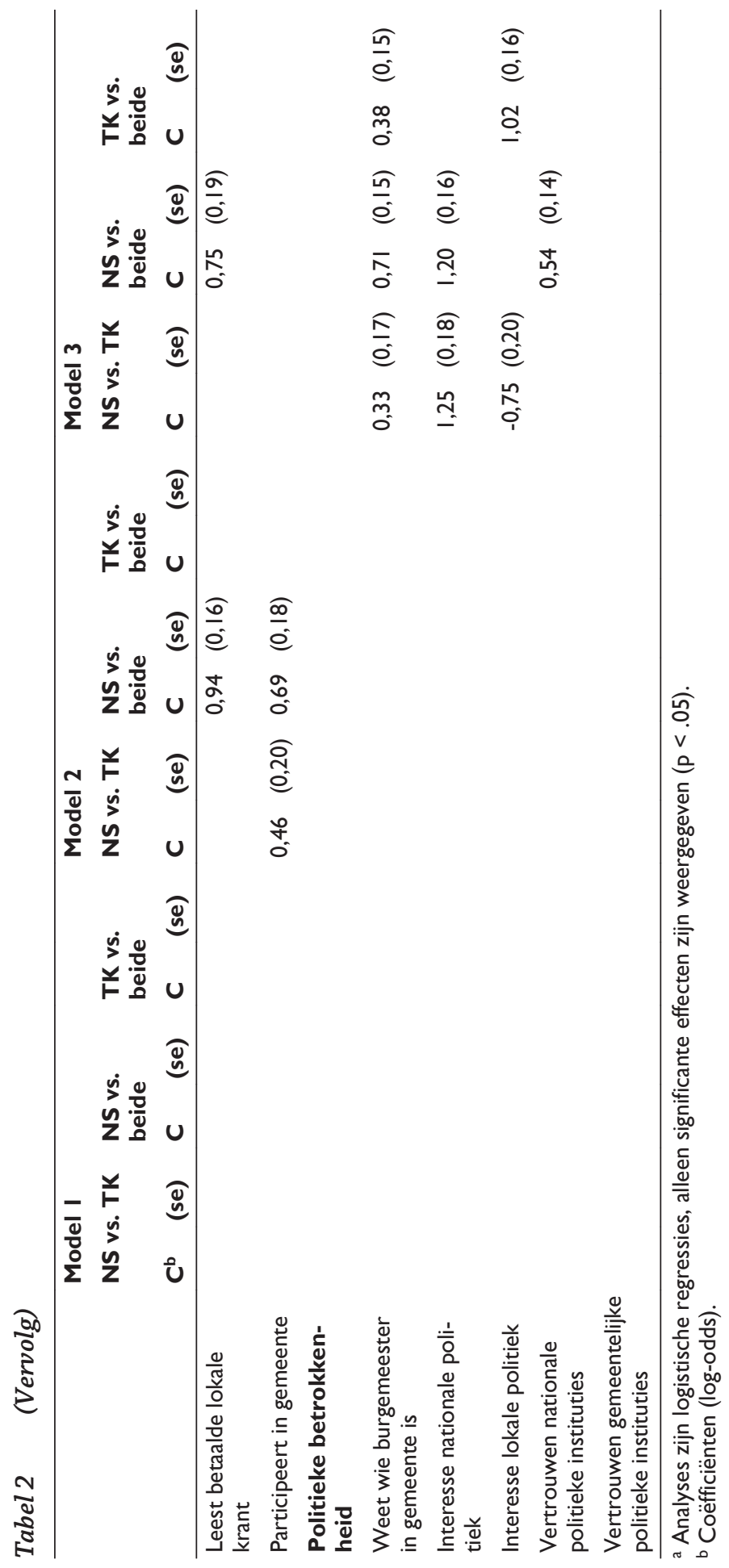


Sociaal-demografische kenmerken zoals leeftijd, opleidingsniveau en inkomen spelen een belangrijke rol bij stemgedrag. Veel studies laten zien dat jongeren minder vaak gaan stemmen, en dat de kans dat men wel gaat stemmen, toeneemt met de leeftijd (Franklin e.a., 2004). Ook opleiding en inkomen hebben een positief effect op het uitbrengen van een stem (Bovens \& Wille, 2011). Veel verklaringen voor deze sociale verschillen in stemgedrag gaan ervan uit dat verschillen in hulpbronnen die mensen hebben, zoals tijd, geld en kennis, daarvoor verantwoordelijk zijn (Brady e.a., 1995). Ook verschillen in engagement, ook wel 'burgerschapszin' genoemd, zoals de houding dat stemmen een burgerplicht is (Blais e.a., 2000; 2011), of in politieke betrokkenheid, zoals politieke kennis en interesse en vertrouwen in de politiek, worden daarvoor verantwoordelijk gehouden (Verba e.a., 1995).

Tabel 2 laat de analyses zien van deze drie typen karakteristieken - (1) sociaaldemografische kenmerken, (2) burgerschapszin en (3) politieke betrokkenheid in drie stappen. In model 1 kijken we alleen naar sociaal-demografische kenmerken, in model 2 voegen we daar factoren rondom burgerschapszin aan toe, en in model 3 komen daar factoren rondom politieke betrokkenheid bij.

In model 1 zien we dat leeftijd, opleiding en inkomen een rol spelen in alle drie de analyses. De stemmers bij beide verkiezingen blijken vergeleken met zowel nietstemmers als TK-stemmers ouder, hogeropgeleid en rijker, maar vergeleken met TK-stemmers zijn de verschillen wel minder pregnant. Dit is in lijn met de hierboven aangehaalde verklaringen rondom hulpbronnen (bijv. Verba e.a., 1995; Bovens \& Wille, 2011) en de leeftijdskloof (Franklin e.a., 2004). Stemmers bij lokale verkiezingen zijn de wat beter gesitueerde, oudere burgers. Deze resultaten komen ook overeen met eerdere studies naar lokaal stemgedrag (Rallings \& Thrasher, 2007: 335; Boogers e.a., 2010; Marien e.a., 2015).

In model 2 zijn ook factoren rondom burgerschapszin opgenomen. Stemmers bij beide verkiezingen vallen op in zowel hun lokale als hun nationale verbondenheid. De stemmers bij de TK zijn nationaal meer geëngageerd dan niet-stemmers, maar lokaal juist minder betrokken dan niet-stemmers, wat aangeeft dat deze groep de betrokkenheid exclusiever richt op het nationale niveau. De burgerschapszin van de kiezers bij beide verkiezingen komt overeen met het (naar ons weten) enige eerdere onderzoek dat lokaal en nationaal stemmen vergelijkt, waar ook de 'sense of civic duty' deze groepen van elkaar onderscheidt (Rallings \& Thrasher, 2007). We kunnen concluderen dat burgerschapszin de stemmers bij beide verkiezingen onderscheidt van zowel niet-stemmers als stemmers bij alleen de TK.

In model 3 hebben we ook de factoren opgenomen die politieke betrokkenheid meten. We zien dat deze factoren goed de beide groepen kiezers wel-stemmers van de niet-stemmers onderscheiden (NS vs. TK en NS vs. beide). Politieke kennis en politieke interesse verhogen de kans op stemmen op zowel lokaal als nationaal niveau. Waarin TK-stemmers te onderscheiden zijn van stemmers bij beide verkiezingen, is dat de eerste groep laag scoort op interesse in de lokale politiek, zelfs 
lager dan niet-stemmers. Stemmers bij beide verkiezingen vallen juist op in hun hoge interesse voor de lokale politiek, en vergeleken met niet-stemmers ook in hun hogere nationaal politiek vertrouwen. Net als voor burgerschapszin kunnen we voor politieke betrokkenheid stellen dat dit algemeen hoog is voor stemmers bij beide verkiezingen, zowel nationaal als lokaal, waar die van alleen TK-stemmers exclusief nationaal gericht is. Een opvallend gebrek aan significantie tekent zich af voor vertrouwen in de lokale politiek. Het is niet zo dat burgers die niet gaan stemmen bij de lokale verkiezingen (NS en TK) relatief weinig vertrouwen hebben in de gemeentepolitiek. Lokaal niet-stemmen kan dus niet zozeer worden toegeschreven aan wantrouwen in de lokale politiek, maar eerder aan onverschilligheid. Ook dit duidt weer op een gebrek aan lokale affiniteit.

We kunnen concluderen dat zowel sociaal-demografische kenmerken als burgerschapszin en politieke betrokkenheid kunnen verklaren waarom burgers gaan stemmen, zowel bij alleen nationale verkiezingen als bij nationale én lokale verkiezingen. Kiezers bij beide verkiezingen vallen op in meer burgerschapszin en politieke betrokkenheid op het lokale niveau. Deze kiezers blijken daarmee inderdaad ook vanwege hun positieve houdingen over de gemeente en de gemeentepolitiek vaker te gaan stemmen. Deze bevindingen nuanceren de literatuur over nationale motieven bij tweedeordeverkiezingen. Onze resultaten spreken niet zozeer studies tegen die laten zien dat de lokale factoren relatief weinig invloed hebben (bijv. Boogers \& Salome, 2014), maar geven wel een inkijk in de verschillen tussen mensen die wel nationaal en niet lokaal willen stemmen enerzijds, en zij die op beide niveaus naar de stembus gaan anderzijds. In die vergelijking speelt lokale betrokkenheid wel degelijk een rol.

\section{Lokale partijen, teken van lokale politieke dynamiek?}

Een kenmerk van de gemeenteraadsverkiezingen is dat er ook lokale partijen meedoen, die geen verbinding hebben met nationale, gevestigde partijen en veelal opkomen voor een specifiek lokaal belang. Dergelijke partijen zijn dus duidelijk sterk verbonden met de lokale politieke context. We kunnen het stemmen op deze partijen dan ook zien als een uiting van een lokale politieke dynamiek, die ingaat tegen het idee van tweedeordeverkiezingen. Anderzijds zijn lokale partijen vaak gevormd in reactie op gevestigde politieke partijen, waardoor ze veelal het karakter hebben van een protestpartij en burgers met weerstand tegen het establishment zullen mobiliseren. In deze paragraaf gaan we na of het stemmen op dergelijke lokale partijen gezien kan worden als een teken van een lokale dynamiek, en daarmee als bewijs tegen lokale verkiezingen als tweedeordeverkiezingen, of eerder als protest tegenover gevestigde politieke partijen.

Allereerst is het van belang te weten hoe groot het aandeel van de stemmen is voor lokale partijen. Figuur 2 laat het percentage stemmen voor lokale partijen zien van 1994 tot 2014. We zien dat het aandeel stemmen voor lokale partijen bij gemeenteraadsverkiezingen substantieel is, en varieert tussen de $19 \%$ in 1994 en $30 \%$ in 2002. In 2014 lag dat op 27\%. In het LKO 2016 ligt het (gewogen) percen- 
Figuur 2 Percentage stemmers voor lokale partijen bij gemeenteraadsverkiezingen 1994-2014

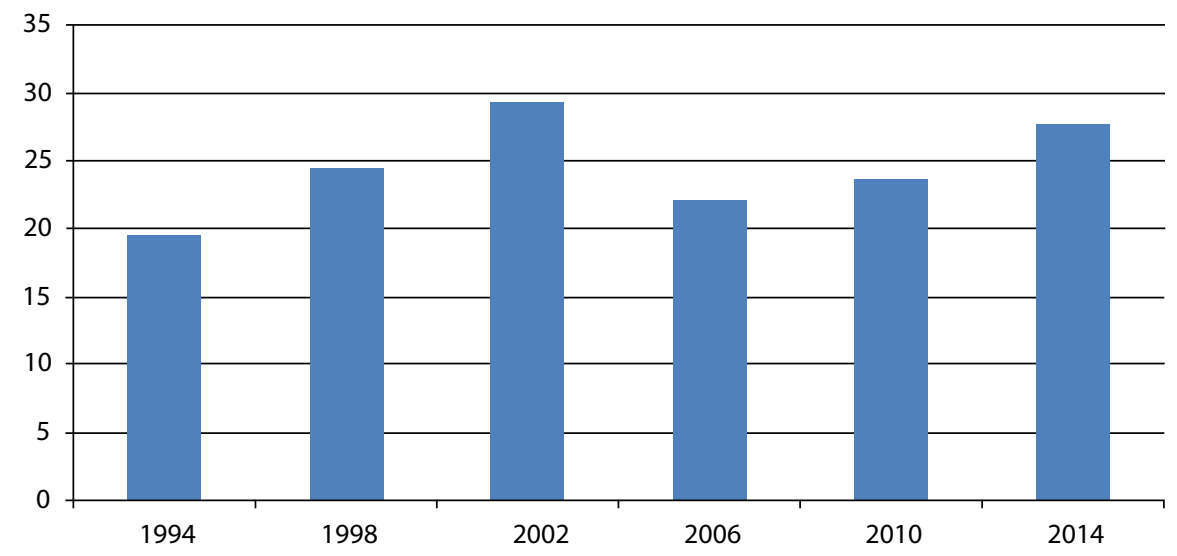

Bron: verkiezingsuitslagen.nl.

tage lager, namelijk op 20\%. Daarmee moeten we vaststellen dat kiezers op lokale partijen duidelijk ondervertegenwoordigd zijn in onze data, wat de validiteit van onze conclusies kan aantasten. Hoewel we dus percentages niet te letterlijk moeten nemen, achten we de patronen wel voldoende betrouwbaar, en bovendien informatief, omdat de vergelijking van karakteristieken tussen kiezers op lokale en nationale partijen bij gemeenteraadsverkiezingen naar ons beste weten nog niet eerder is gemaakt.

Omdat ons geen eerder onderzoek bekend is van de kenmerken van kiezers van lokale partijen, houden we dezelfde drie verklaringsmodellen aan als bij tabel 2: sociaal-demografische kenmerken, burgerschapszin en politieke betrokkenheid. Model 1 laat zien dat opleiding een negatief effect heeft op het stemmen op lokale partijen. Model 2 toont dat opleiding niet meer significant is als burgerschapszin wordt meegenomen in het model, en dat dan de verbondenheid met Nederland en het lezen van nationale kranten een negatief effect hebben. Blijkbaar is lage nationale burgerschapszin de mediërende factor tussen het negatieve effect van opleiding op het stemmen op een lokale partij; laagopgeleiden stemmen vaker op deze partijen omdat ze vervreemd zijn van de nationale gemeenschap. 
Tabel $3 \quad$ Vergelijking stemmen voor landelijke versus lokale partij bij gemeenteraadsverkiezingen $2014^{a}$

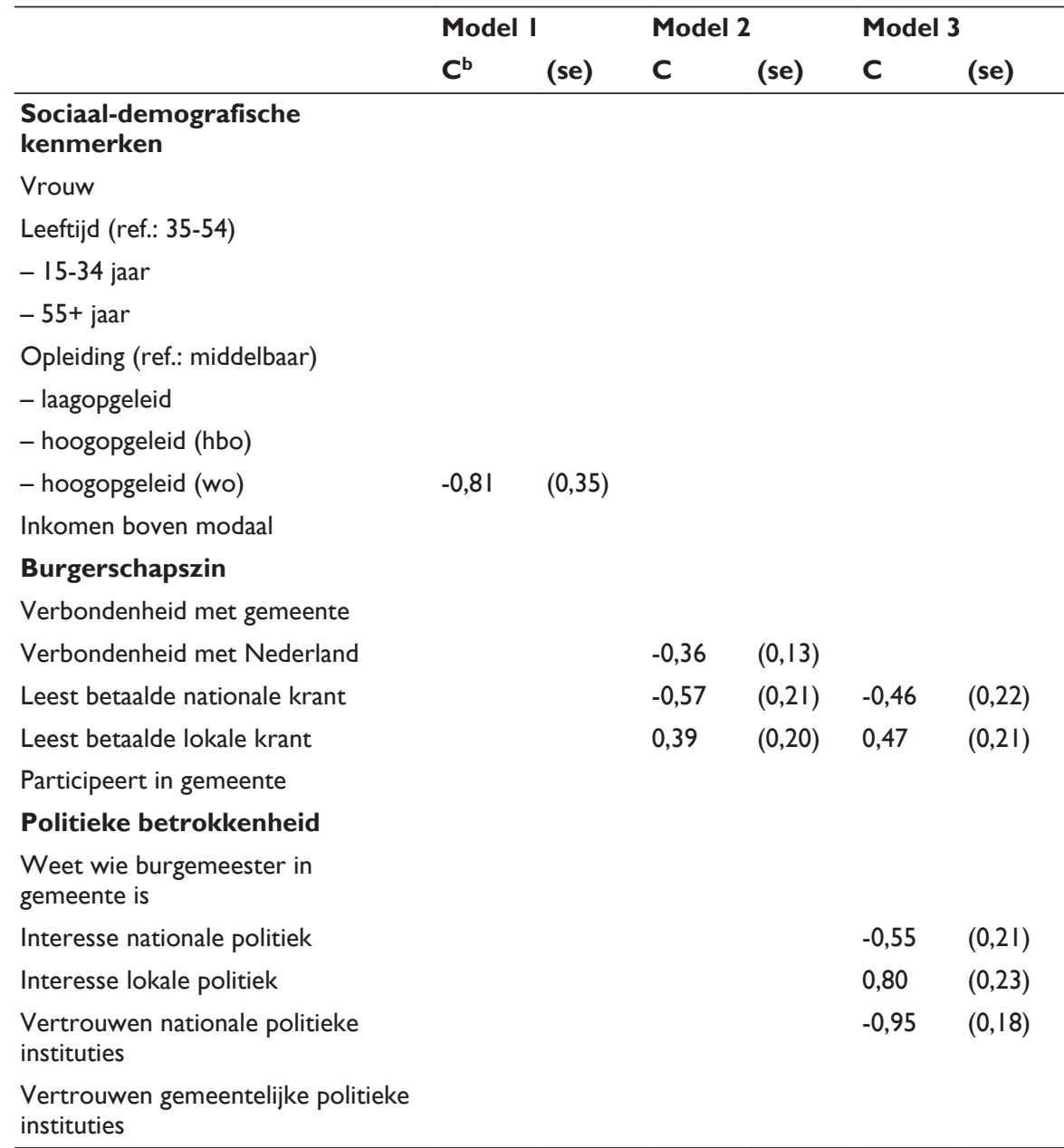

${ }^{a}$ Analyses zijn logistische regressies, alleen significante effecten zijn weergegeven $(p<.05)$.

${ }^{b}$ Coëfficiënten (log-odds).

Model 3 laat zien dat wanneer we politieke betrokkenheid aan het model toevoegen, we een negatief effect van nationale politieke interesse en vertrouwen in de nationale politiek vinden, en een positief effect van interesse in de lokale politiek. Opvallend is dat de kiezers van lokale partijen niet een sterkere binding met de gemeente laten zien, noch meer vertrouwen in de lokale politiek.

We kunnen daarmee concluderen dat het stemmen op lokale partijen vooral wordt veroorzaakt door een sterke interesse in de lokale politiek, en een desinteresse en wantrouwen in de nationale politiek. Een dergelijk profiel spreekt enerzijds het tweedeordekarakter van de lokale verkiezingen tegen vanwege de grote lokale politieke interesse, maar anderzijds doet de nationale politiek er nog altijd 
Figuur 3 Landelijk stemgedrag van kiezers van lokale partijen bij gemeenteraadsverkiezingen

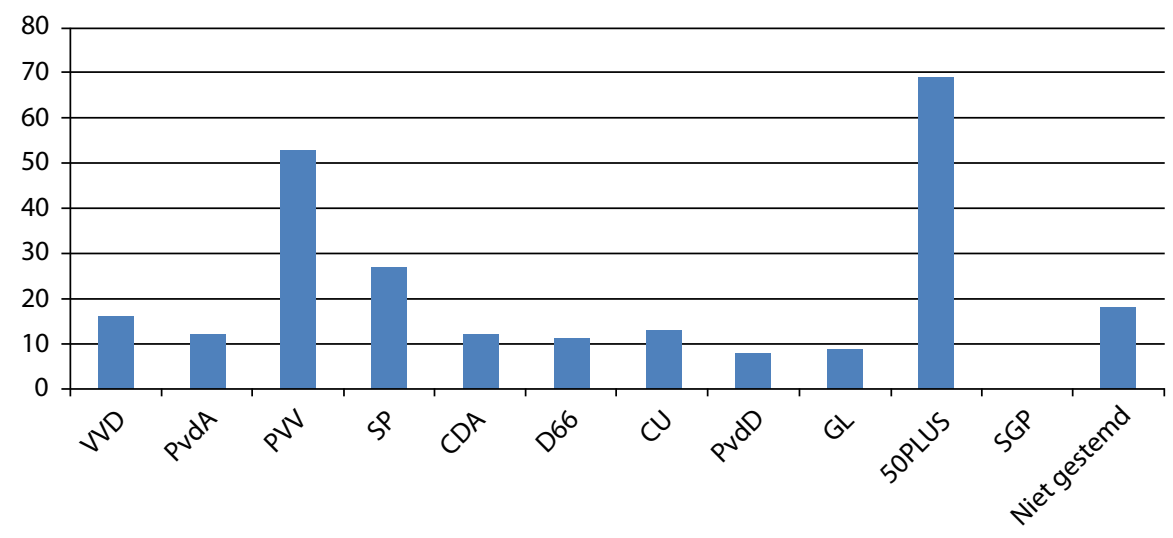

sterk toe, alleen dan in negatieve zin. Lokale partijen lijken daarmee ook een wantrouwen jegens de (nationale) gevestigde politiek te vertolken.

Om dit verder na te gaan geven we in figuur 3 voor de kiezers van lokale partijen weer op welke nationale partij ze hebben gestemd bij de Tweede Kamerverkiezingen van 2012. De aantallen zijn klein, maar het patroon is wel sprekend. We zien dat deze kiezers nationaal in de eerste plaats stemden op 50PLUS, gevolgd door de PVV. Daarna komen SP en niet-stemmen. Ondanks de grote verschillen tussen deze partijen zijn er ook overeenkomsten. Ten eerste doen ze, op de SP na, lokaal niet (op grote schaal) mee aan de gemeenteraadsverkiezingen. Daarom zijn hun kiezers wellicht ook eerder geneigd om op lokale partijen te stemmen. Ten tweede vertolken al deze partijen op het nationale niveau een stem tegen de gevestigde politiek. Dit suggereert sterk dat het stemmen op lokale partijen inderdaad als proteststemmen kan worden opgevat. Nader onderzoek is nodig om dit verder te onderbouwen.

\section{Stemmotivatie bij lokale verkiezingen - nationaal of lokaal?}

In eerder onderzoek naar lokale verkiezingen komen verschillende bevindingen naar voren over de stemmotieven die burgers daarbij hanteren. Waar sommige studies concluderen dat nationale motieven de boventoon voeren (Boogers \& Salome, 2014), vinden andere juist dat lokale motieven het belangrijkst zijn (Marien e.a., 2015). In het laatste deel van dit artikel gaan we na welke motieven burgers aandragen voor hun stem bij de gemeenteraadsverkiezingen, en in hoeverre nationale of lokale motieven de boventoon voeren. 
Hierbij zullen we ook nagaan of er motieven worden genoemd die centraal staan in onderzoek naar tweedeordeverkiezingen: 'proteststemmen' (protest voting) en 'hartstemmen' (heart voting) (bijv. Reif, 1984; Van der Eijk e.a., 1996). Bij proteststemmen tonen kiezers hun ontevredenheid over het beleid van de zittende nationale regering met een stem op kleine of radicale partijen. Dit gebeurt meestal wanneer de tweedeordeverkiezingen plaatsvinden in het midden van de regeringstermijn, wanneer de onvrede vaak het grootst is (Reif, 1984; Heath e.a., 1999; Ervik, 2012). Met hartstemmen bedoelt men het tegenovergestelde van strategisch stemmen. Op het nationale niveau stemmen kiezers soms strategisch, op een partij die kans had te winnen maar niet de eerste keus was. Omdat bij tweedeordeverkiezingen minder op het spel staat, zo is de gedachte, kunnen mensen die nationaal strategisch stemden bij tweedeordeverkiezingen wel hun hart volgen, en zodoende op de partij van hun eerste keus stemmen.

In het LKO 2016 is nagegaan of men op dezelfde partij heeft gestemd bij de gemeenteraadsverkiezingen 2014 als bij de Tweede Kamerverkiezingen van 2012, en waarom men dat wel of niet heeft gedaan. Van de respondenten die een stem hebben uitgebracht, geeft $25 \%$ een toelichting waarom ze hetzelfde stemden en $25 \%$ waarom ze iets anders stemden.

\subsection{Stemmotieven bij gemeenteraadsverkiezingen 2014: dezelfde partij als bij de Tweede Kamer}

We zullen eerst de motieven bekijken om wel op dezelfde partij te stemmen. Tabel 4 toont deze motieven, die uiteenvallen in tien categorieën, gesorteerd naar landelijke (categorie 1-4) en lokale motieven (categorie 5), en noch landelijk, noch lokaal (categorie 6-10). Hierbij valt op dat de landelijke motieven aanzienlijk vaker voorkomen (80\%) dan de lokale motieven (10\%). Als we beginnen met de landelijke motieven, zien we in categorie 1 (21\%) argumenten als dat men lid is van de partij, al jaren op die partij stemt, of uit gewoonte dan wel traditie op de betreffende partij stemt. De antwoorden in deze categorie geven aan dat men al langere tijd consequent voor dezelfde partij kiest. Voorbeelden zijn:

'Dit doe ik al vanaf mijn 18e jaar'

'Partij waar ik gewoon achter sta'

'Het is mijn partij'

'Ik ben lid van de partij'

Categorie 2 is verreweg het grootst (56\%) en omvat argumenten die ook blijk geven van grote steun aan de partij, maar waarbij niet kan worden vastgesteld dat deze politieke voorkeur al langere tijd bestaat. Mensen geven aan dat de uitgangspunten, waarden of visie van de partij het beste bij hen past, dat zij zich thuis voelen bij de partij, of dat de partij hen aanspreekt. Dit type argumenten lijkt op die in categorie 1, behalve dat er niet expliciet wordt gezegd dat men aan deze partij verbonden is door lidmaatschap of langdurige steun. Voorbeelden zijn: 
'Omdat dat wat zij denken het beste past bij mijn manier van denken'

'De kern van waar men voor staat is bij beide plaatsen hetzelfde!!!'

'Ik voel me het meest thuis bij deze partij'

'Ik sta achter de uitgangspunten van de partij'

Een nationaal argument bij uitstek vinden we terug in categorie 3 (2\%), namelijk dat men 'uit principe liever op een landelijke partij stemt' of vindt dat 'de plaatselijke politiek te weinig invloed kan uitoefenen op het gemeentelijke beleid dat vanuit Den Haag grotendeels wordt opgelegd'. Een andere reden om op dezelfde landelijke partij te stemmen is gemakzucht. Men vindt het te ingewikkeld om de standpunten precies na te gaan (categorie 4: 1\%).

Er is slechts één motief dat we als lokaal betitelen bij de burgers die lokaal hetzelfde stemden als nationaal (categorie 5: 10\%). Daarbij staat centraal dat men wel degelijk opnieuw actief voor deze partij heeft gekozen. Anders verwoord: alle antwoorden in categorie 5 duiden erop dat de keuze voor dezelfde partij bij de lokale verkiezingen als bij de nationale verkiezingen geen vanzelfsprekende maar een weloverwogen keuze was. Soms wordt daarbij zelfs aangegeven dat men nu die keuze niet meer zou maken. De stemkeuze volgde bijvoorbeeld uit de stemwijzer of uit het vergelijken van verkiezingsprogramma's.

'Standpunten kwamen redelijk overeen'

'Heel toevallig zijn de belangen in [X] goed vertegenwoordigd door de partij die ook landelijk mijn voorkeur heeft'

'Kwam uit de kieswijzers'

'Omdat ik me in beide programma's wel kon vinden'

In categorie 6 (5\%) geeft men aan dezelfde partij te hebben gekozen omdat die specifieke beleidsdoelen heeft die zij belangrijk vinden, zoals onderwijs, ondernemers, gelijkheid, sociaal beleid of groen beleid. Hieruit blijkt niet of men deze beleidsdoelen speciaal bij de gemeente belangrijk vindt of in het algemeen. Daarom hebben we deze antwoorden geschaard onder 'noch landelijk, noch lokaal'.

\section{'Ik stem altijd zo groen mogelijk'}

'Ik stem niet op een linkse partij omdat ik het niet eens ben met uitgangspunt verdelen en nivelleren'

'Ik ben een werknemer'

'Omdat deze partij het beste sociaal programma heeft'

'Wij werken in de agrarische sector. CDA is dan de beste keuze'

In categorie 7 (3\%) zijn antwoorden opgenomen waarmee de respondenten aangeven dat de gekozen partij de minst slechte optie is. Ook hier is niet duidelijk een landelijk of een lokaal motief te ontwaren. 
Tabel $4 \quad$ Waarom mensen op dezelfde partij hebben gestemd bij de gemeenteraadsverkiezingen 2014 en bij de Tweede Kamerverkiezingen $2012(\%)^{a}$

\begin{tabular}{lrr}
\hline Nationale motieven & $\mathbf{8 0}$ \\
\hline & Lid, traditie, of stem al jaren op deze partij & 21 \\
2 & Sta achter deze kernprincipes, idealen, standpunten & 56 \\
3 & Stem liever op landelijke partij & 2 \\
4 & Gemakkelijk & I \\
Lokale & motieven & 10 \\
5 & Beide keren beste programma & 10 \\
Noch landelijk, noch lokaal & 12 \\
6 & Specifieke beleidspunten & 5 \\
7 & Minst slechte partij & 3 \\
8 & Overig & 2 \\
9 & Weet niet & I \\
10 & Toeval & I \\
\hline
\end{tabular}

${ }^{a}$ Omdat het afgeronde cijfers betreft, tellen de categorieën op tot 102 in plaats van 100.

'De enigste partij waar ik nog een heel klein beetje vertrouwen in heb' 'Het is moeilijk een echte eerlijke partij te vinden dus tja wat moet je' 'Er is geen andere goede partij'

'De minst slechte partij om op te stemmen'

Ten slotte geven sommigen aan dat het toeval is (2\%), dat ze het niet weten (1\%), of geven ze een ander argument, ondergebracht in de categorie 'overig' (1\%).

\subsection{Stemmotieven bij gemeenteraadsverkiezingen 2014: een andere partij dan bij de}

\section{Tweede Kamer}

Ook de stemmotieven van degenen die bij de Tweede Kamerverkiezingen 2012 en de gemeenteraadsverkiezingen 2014 op verschillende partijen hebben gestemd, hebben we in kaart gebracht. Hier verwachten we in beginsel meer mensen die een lokale motivatie aangeven, omdat ze wellicht van partij wisselden vanwege de lokale politieke context. Tabel 5 geeft antwoorden verdeeld over dertien categorieën weer. We zien hier veel meer variatie in stemmotieven dan bij respondenten die nationaal en lokaal op dezelfde partij stemden. Daarnaast is er nu inderdaad een veel grotere lokale component te ontwaren: lokale motieven vormen met $41 \%$ weliswaar nog een minderheid, maar omvatten aanzienlijk meer antwoorden dan de $10 \%$ in paragraaf 5.1. De nationale motieven zijn dus nog wel in de meerderheid (55\%). We lopen ze kort langs.

Bij de nationale motieven geeft $20 \%$ aan dat de landelijke partij waarop ze lokaal ook wilden stemmen niet meedeed in hun gemeente. Dat is duidelijk een nationaal ingegeven stem. Ook een aanzienlijke groep (10\%) geeft aan dat 'hun' natio- 
Tabel $5 \quad$ Waarom mensen op een andere partij hebben gestemd bij de gemeenteraadsverkiezingen 2014 dan bij de Tweede Kamerverkiezingen 2012 (\%)

\begin{tabular}{llr}
\hline Nationale motivatie & $\mathbf{5 4}$ \\
\hline & Landelijke partij niet lokaal & 20 \\
2 & Gewisseld van partijvoorkeur (niet vanwege lokaal) & 16 \\
3 & Wel hetzelfde gestemd (lijstverbinding) & 10 \\
4 & Landelijk strategisch gestemd (hartstem) & 5 \\
5 & Stem tegen PvdA/VVD (proteststem) & 3 \\
Lokale & motivatie & 4 I \\
6 & Andere belangen lokaal en nationaal & 18 \\
7 & Stemt graag op een lokale partij & 10 \\
8 & Verschil tussen partijen landelijk en lokaal & 6 \\
9 & Lokaal gestemd op persoon & 4 \\
10 & Lokale partij niet landelijk & 2 \\
II & Partij is lokaal niet sterk & I \\
Noch nationaal, noch lokaal & $\mathbf{5}$ \\
I2 & Weet niet & I \\
13 & Overig & 4 \\
\hline
\end{tabular}

nale partij een lijstverbinding is aangegaan met de partij waar ze lokaal op stemden. Beide groepen zijn dus eigenlijk niet veranderd in voorkeur en hebben een duidelijk nationale motivatie. Ook een substantiële groep (16\%) geeft aan veranderd te zijn van partijvoorkeur, maar noemt daarbij geen lokale argumenten, en de verandering lijkt dus eerder ingegeven te zijn door nationale motieven. Redenen zijn bijvoorbeeld dat men teleurgesteld is geraakt in de partij waar men op stemde in 2012, omdat de verkiezingsprogramma's in 2014 tot een andere keuze leidden, of omdat men nu eenmaal geen vaste voorkeur heeft:

'Ik kijk per keer naar de standpunten van dat moment.'
'Op basis van het programma van de partij'
'Andere opinies op de kiesmomenten'
'Ik twijfel vaak tussen deze 2 partijen'

De twee nationale stemmotieven uit de literatuur, de proteststem en de hartstem, komen we in beperkte mate tegen. Slechts $5 \%$ van de respondenten geeft aan bij de landelijke verkiezingen strategisch te hebben gestemd en nu weer op de eerste voorkeur te hebben gestemd:

'Voor de Tweede Kamerverkiezing was er een grote kans dat het tussen PvdA en VVD zou gaan, daarom gekozen voor PvdA en niet GroenLinks' 
'Dat was een tactische stem om de PVV zo min mogelijk kans op zetels te geven' 'Strategische keuze om toen de VVD te laten winnen'

Wat betreft proteststemmen zijn de aantallen nog kleiner, slechts 3\% van de respondenten is uit protest gewisseld van de PvdA of de VVD. We komen in het geheel geen antwoorden tegen die erop wijzen dat kiezers van een andere landelijke partijvoorkeur een proteststem tegen de regering hebben geuit. Deze bevindingen spreken dan ook het idee van proteststemmen bij tweedeordeverkiezingen tegen op het lokale niveau.

\section{'Afgeknapt op de VVD'}

'Teleurgesteld in de PvdA'

Als we dan naar de lokale motieven gaan, is een veelgenoemd (18\%) argument dat er lokaal andere belangen spelen dan nationaal, en men daarom een andere afweging maakt:

'Gemeenteraadsverkiezingen gaan om lokale belangen, niet het nationale beleid.'

'Gemeentebelang is een andere dan het landelijke belang'

'Gemeente gaat over de gemeente en de kamer over het land'

Ook een aanzienlijke groep (10\%) stemt bij gemeenteraadsverkiezingen graag op een lokale partij. Bij dergelijke antwoorden lijkt het alsof men denkt dat lokale partijen de lokale belangen beter kunnen vertegenwoordigen:

'Bij een gemeenteraadsverkiezing kies ik liever een lokale partij.'

'Op gemeenteraadsverkiezingen gaat mijn voorkeur naar een onafhankelijke partij'

'Een plaatselijke partij heeft meer oog voor de belangen van de stad dan een landelijke partij'

'Bij gemeenteverkiezing stem ik lokaal'

Een kleinere groep (6\%) noemt als reden dat partijen landelijk en gemeentelijk andere programma's hebben en ze dan bij een andere keuze uitkomen, of dat andere issues de doorslag geven:

'Omdat het gemeenteprogramma niet hetzelfde is als de landelijke politiek. Bij de gemeente kijk ik meer wat ik belangrijk vind in mijn stad en dat staat soms wat haaks op het programma van de landelijke politiek'

'Programma's vergeleken en bekeken wat ik in de gemeentelijke en landelijke context het beste vond'

'Bij de gemeenteraad verkiezingen stem ik op de partij die het beste programma voorstelde voor de kern waar ik woon'

Verder is er een aantal argumenten die door een kleine groep respondenten worden aangedragen. Sommigen (4\%) geven aan op iemand te hebben gestemd die ze persoonlijk kennen, of op een specifieke wethouder of raadslid. Anderen schrijven 
dat de lokale partij landelijk niet verkiesbaar was (2\%), of geven aan dat de landelijke partij in hun gemeente zwak stond (en dus niet het verschil kon maken) (1\%). De categorie overig bevat $4 \%$ van de antwoorden die niet elders geplaatst konden worden, en $1 \%$ geeft aan het niet te weten.

Concluderend kunnen we stellen dat de stemmotieven bij de gemeenteraadsverkiezingen vooral nationaal zijn ingegeven, al zien we bij een minderheid wel degelijk ook lokale motieven. De nationale motieven die in de literatuur worden genoemd, namelijk proteststemmen en hartstemmen, komen echter slechts weinig voor. Dit pleit dus weer tegen het veronderstelde tweedeordekarakter, blijkbaar vinden respondenten niet dat er bij de gemeenteraadsverkiezingen zo weinig op het spel staat dat ze dergelijke motieven laten prevaleren.

\section{Conclusies}

De literatuur over lokale verkiezingen is verdeeld over het zogenaamde tweedeordekarakter ervan. Hoewel sommige studies dit onderschrijven, en vinden dat nationale factoren een belangrijke rol spelen bij gemeenteraadsverkiezingen (Van der Kolk, 1997; Boogers \& Van Ostaaijen, 2011; Boogers \& Salome, 2014; Lelieveldt \& Van der Does, 2014), laten andere zien dat dit minder sterk geldt dan verwacht (Marien e.a., 2015), en dat kiezers zich bij lokale verkiezingen minder dan bij Europese laten leiden door de nationale politiek (Heath e.a., 1999). Voortbouwend op deze literatuur over tweedeordeverkiezingen is de vraag die in dit artikel centraal staat, hoe lokaal geïnspireerd de Nederlandse gemeenteraadsverkiezingen zijn. Invloed van lokale factoren zou hierbij een tweedeordekarakter tegenspreken, terwijl invloed van nationale factoren het zou onderschrijven.

De resultaten geven geen eenduidig antwoord op de vraag in hoeverre gemeenteraadsverkiezingen lokaal georiënteerd zijn. De vier verschillende invalshoeken die we hebben gebruikt - het vergelijken van (1) opkomstpercentages, (2) factoren die opkomst bij nationale en lokale verkiezingen verklaren, (3) factoren die stemmen op lokale partijen verklaren, en (4) het analyseren van stemmotivaties leveren allemaal dubbelzinnige patronen op.

Enerzijds onderschrijven onze resultaten het tweedeordekarakter van de gemeenteraadsverkiezingen. Zo is de opkomst bij de gemeenteraadsverkiezingen duidelijk lager dan bij de Tweede Kamerverkiezingen, en is dit patroon al geruime tijd zichtbaar. Onze analyses laten ook zien dat er niet zoiets bestaat als een groep lokale kiezers, burgers die alleen bij de gemeenteraadsverkiezingen stemmen en niet nationaal, wat zou duiden op een lokale stimulans om te gaan stemmen los van de nationale politiek. Burgers die wel gaan stemmen bij de gemeenteraadsverkiezingen doen dit bijna altijd ook bij nationale verkiezingen. Ze vallen op in hun burgerschapszin, en wellicht stemmen zij dan ook deels uit plichtsbesef. Burgers die niet gaan stemmen bij de gemeenteraadsverkiezingen staan niet meer wantrouwend tegenover de lokale politiek dan zij die dat wel doen. Het lijkt daarmee dan ook eerder onverschilligheid die de lokale niet-stemmers thuis houdt dan 
onvrede. Bovendien is het stemmen op een lokale partij deels ingegeven door onvrede over de nationale, gevestigde politiek. Ten slotte blijkt uit de analyse van stemmotivaties dat nationale motieven de boventoon voeren.

Anderzijds laten de analyses ook zien dat bij de gemeenteraadsverkiezingen wel degelijk lokale factoren een rol spelen, wat ingaat tegen het idee van tweedeordeverkiezingen. Zo is de opkomst weliswaar lager dan bij Tweede Kamerverkiezingen, maar nog altijd hoger dan bij Europese verkiezingen. Bovendien is het stemmen bij de gemeenteraadsverkiezingen ook duidelijk ingegeven door lokale burgerschapszin en lokale politieke betrokkenheid. Gebrek aan lokale betrokkenheid verklaart ook waarom sommige burgers alleen bij de Tweede Kamerverkiezingen stemmen. Als we kijken naar het stemmen op lokale partijen, blijkt ook hier lokale politieke interesse een factor van belang. Ten slotte heeft een grote minderheid wel degelijk lokaal geïnspireerde stemmotieven, en blijken de in de literatuur veronderstelde centrale nationale motieven, protest voting (tegen de zittende regering) en heart voting (stemmen voor de eerste keuze omdat strategisch belang wegvalt) (Reif, 1984; Van der Eijk e.a., 1996), nauwelijks aanwezig.

We kunnen dus vaststellen dat gemeenteraadsverkiezingen inderdaad deels een tweedeordekarakter hebben, zoals eerder betoogd en getoond. Toch mogen we de lokale affiniteit en politieke betrokkenheid ook niet onderschatten. Dat een deel van de burgers zich wel interesseert in de lokale politiek, in lokale partijen en in verkiezingsprogramma's van lokale afdelingen wijst wel degelijk op een lokale politieke dynamiek.

Een belangrijke vervolgstap ligt in het toetsen van het belang van politieke prestaties. In de institutionele literatuur zien we vaak de redenering dat kiezers wan-/ vertrouwen hebben in de politiek vanwege het falen/succes in termen van beleid (Mishler \& Rose, 2001; Van Erkel \& Van der Meer, 2016; Van der Meer \& Hakhverdian, 2017). Een vraag die we hier niet hebben kunnen beantwoorden, is of tevredenheid met lokaal beleid, bijvoorbeeld rondom veiligheid of huisvesting, die belangrijke lokale thema's blijken voor burgers in een ander artikel in dit special issue (Van der Waal e.a.), een effect heeft op het stemmen bij gemeenteraadsverkiezingen. En of dergelijke tevredenheid van groter belang is dan die met nationaal beleid. Een vervolgstap in het toetsen van het nationale tweedeordekarakter van lokale verkiezingen ligt dan ook bij het nagaan van de invloed van nationale en lokale beleidsprestaties op het lokale stemgedrag.

Specifieke aandacht verdient de invloed van de tevredenheid met het sociale beleid bij toekomstige gemeenteraadsverkiezingen. De decentralisatie van sociaal beleid die door Rutte II is ingezet, zal steeds meer tot uiting komen in lokale politieke keuzes en programma's. Het is van belang om na te gaan of tevredenheid met het gevoerde lokale sociale beleid een factor van belang is bij nieuwe lokale verkiezingen. Bovendien is het de vraag of deze decentralisatie het tweedeordekarakter van gemeenteraadsverkiezingen doet afnemen, vanwege vergrote lokale belangen, zoals wel in de literatuur verondersteld en aangetoond (Michelsen e.a., 2014). 


\section{Literatuur}

Blais, A., E. Anduiza \& A. Gallego, 'Decentralization and voter turnout', Environment and Planning C: Government and Policy, 2011/2, p. 297-320.

Blais, A., R. Young \& M. Lapp, 'The calculus of voting. An empirical test', European Journal of Political Research, 2000/2, p. 181-201.

Boogers, M.J.G.J.A. \& J.J.C. van Ostaaijen, 'Lokale kiezers, lokale keuzes? Onderzoek naar de achtergronden en de betekenis van het stemgedrag bij de gemeenteraadsverkiezingen van 2010', Bestuurswetenschappen, 2011/6, p. 17-39.

Boogers, M.J.G.J.A. \& L. Salome, Gemeenteraadsverkiezingen 2014. Wie stemt, wat en waarom?, BMC, Amersfoort: 2014. Gedownload op 15 juni 2017 via kennisopenbaarbestuur.nl/rapporten-publicaties/gemeenteraadsverkiezingen-2014-wie-stemt-waten-waarom/.

Boogers, M.J.G.J.A., J.J.C. van Ostaaijen \& L. Slagter, Lokale kiezers. Lokale keuzes?, Tilburgse School voor Politiek en Bestuur, Tilburg: 2010. Gedownload op 15 juni 2017 via www.raadtilburg.nl/_admin/_script/ckfinder/userfiles/files/Lokale\%20Kiezers \%20Lokale\%20Keuzes\%20-\%20eindversie.pdf.

Bovens, M.A.P. \& A. Wille, Diplomademocratie. Over de spanning tussen meritocratie en democratie, Amsterdam: 2011.

Brady, H.E., S. Verba \& K.L. Schlozman, 'Beyond SES. A resource model of political participation', American Political Science Review, 1995/2, p. 271-294.

Carruba, C. \& R.J. Timpone, 'Explaining vote switching across first- and second-order elections. Evidence from Europe', Comparative Political Studies, 2005/3, p. 260-281.

Eijk, C. van der, M. Franklin \& M. Marsh, 'What voters teach us about Europe-wide elections. What Europe-wide elections teach us about voters', Electoral Studies, 1996/2, p. 149-166.

Erkel, P.F. van \& T.W.G. van der Meer, 'Macroeconomic performance, political trust and the Great Recession. A multilevel analysis of the effects of within-country fluctuations in macroeconomic performance on political trust in 15 EU countries, 1999-2011', European Journal of Political Research, 2016/1, p. 177-197.

Ervik, B., 'Second-order arguments for second-order elections? Measuring "election stakes" in a multilevel context. The case of Norway', Journal of Elections, Public Opinion and Parties, 2012/1, p. 27-50.

Franklin, M.N. \& S.B. Hobolt, 'The legacy of lethargy. How elections to the European Parliament depress turnout', Electoral Studies, 2011/1, p. 67-76.

Franklin, M.N., P. Lyons \& M. Marsh, 'The generational basis of turnout decline in established democracies', Acta Politica, 2004/2, p. 115-151.

Heath, A., I. McLean, B. Taylor \& J. Curtice, 'Between first and second order. A comparison of voting behaviour in European and local elections in Britain', European Journal of Political Research, 1999/3, p. 389-414.

Hix, S. \& M. Marsh, 'Punishment or protest? Understanding European Parliament elections', Journal of Politics, 2007/2, p. 495-510.

Kolk, H. van der, Electorale controle. Lokale verkiezingen en responsiviteit van politici, Enschede: 1997.

Lelieveldt, H.T. \& R. van der Does, 'Hoe tweederangs zijn lokale verkiezingen? Een analyse van de Nederlandse gemeenteraadsverkiezingen 2010 vanuit het perspectief van second-order elections', Res Publica, 2014/3, p. 1-22.

Marien, S., R. Dassonneville \& M. Hooghe, 'How second order are local elections? Voting motives and party preferences in Belgian municipal elections', Local Government Studies, 2015/6, p. 898-916. 
Marsh, M. \& S. Mikhaylov, 'European Parliament elections and EU governance', Living Reviews in European Governance, 2010/4, p. 5-30.

Meer, T.W.G. van der \& A. Hakhverdian, 'Political trust as the evaluation of process and performance. A cross-national study of forty-two European democracies', Political Studies, 2017/1, p. 81-102.

Michelsen, C., P. Boenisch \& B. Geys, '(De)centralization and voter turnout. Theory and evidence from German municipalities', Public Choice, 2014/3-4, p. 469-483.

Mishler, W. \& R. Rose, 'What are the origins of political trust? Testing institutional and cultural theories in post-communist societies', Comparative Political Studies, 2001/1, p. 30-62.

Rallings, C. \& M. Thrasher, "The turnout "gap" and the costs of voting. A comparison of participation at the 2001 general and 2002 local elections in England', Public Choice, 2007/3, p. 333-344.

Reif, K., 'National electoral cycles and European elections 1979 and 1984', Electoral Studies, 1984/3, p. 244-255.

Reif, K. \& H. Schmitt, 'Nine second-order national elections. A conceptual framework for the analysis of European election results', European Journal of Political Research, 1980/1, p. 3-44.

Verba, S., K.L. Schlozman \& H.E. Brady, Voice and equality. Civic voluntarism in American Politics, Cambridge: 1995.

\section{Bijlage}

Tabel A Operationalisering van de gebruikte variabelen

\begin{tabular}{ll}
\hline Variabelen & Vraag \\
\hline Stemvariabelen & \\
Opkomst Tweede & 'Hebt u gestemd tijdens de Tweede \\
Kamerverkiezingen & Kamerverkiezingen van 20I2?' \\
2012 &
\end{tabular}

Opkomst gemeenteraadsverkiezingen 2014

Stemmen voor lokale partij

'Hebt u gestemd tijdens de gemeenteraadsverkiezingen van 20I4?'

Codering CentERdata: Stemmen voor lokale partij versus landelijke partij bij gemeenteraadsverkiezingen 2014
Antwoordcategorieën

$0=$ nee

$\mathrm{I}=\mathrm{ja}$

(lk mocht niet stemmen/lk wil het niet zeggen/lk weet het niet $=$ gecodeerd als missend)

$0=$ nee

$\mathrm{I}=$ ja

(Ik mocht niet stemmen/lk wil het niet zeggen/lk weet het niet $=$ gecodeerd als missend)

$0=$ landelijke partij

I = lokale partij

vrouw $=1$

$\operatorname{man}=0$ 
Tabel A (Vervolg)

\begin{tabular}{|c|c|c|}
\hline Variabelen & Vraag & Antwoordcategorieën \\
\hline Leeftijd & & $\begin{array}{l}\text { I5-34 jaar } \\
35-54 \text { jaar (referentie- } \\
\text { groep) } \\
55+\text { jaar }\end{array}$ \\
\hline Opleidingsniveau & & $\begin{array}{l}\text { laagopgeleid (basisonder- } \\
\text { wijs/vmbo) } \\
\text { middelbaar (havo/vwo/ } \\
\text { mbo) } \\
\text { hoogopgeleid (hbo) } \\
\text { hoogopgeleid (wo) }\end{array}$ \\
\hline $\begin{array}{l}\text { Inkomen boven } \\
\text { modaal }\end{array}$ & $\begin{array}{l}\text { Persoonlijk netto maandinkomen in } \\
\text { categorieën }\end{array}$ & $\begin{array}{l}\text { Inkomen onder modaal = } \\
\text { geen inkomen-I } 500 \text { per } \\
\text { maand } \\
\text { Inkomen boven modaal = } \\
\text { I50I-meer dan } 7400 \text { per } \\
\text { maand } \\
\text { (wil het niet zeggen = geco- } \\
\text { deerd als missend) }\end{array}$ \\
\hline \multicolumn{3}{|l|}{ Burgerschapszin } \\
\hline $\begin{array}{l}\text { Verbondenheid met } \\
\text { gemeente }\end{array}$ & $\begin{array}{l}\text { 'In welke mate voelt u zich verbon- } \\
\text { den met uw gemeente?' }\end{array}$ & $\begin{array}{l}0=\text { helemaal niet/niet erg } \\
\text { verbonden } \\
I=\text { tamelijk/zeer verbon- } \\
\text { den } \\
\text { (weet niet = gecodeerd als } \\
\text { missend) }\end{array}$ \\
\hline $\begin{array}{l}\text { Verbondenheid met } \\
\text { Nederland }\end{array}$ & $\begin{array}{l}\text { 'In welke mate voelt u zich verbon- } \\
\text { den met Nederland?' }\end{array}$ & $\begin{array}{l}0=\text { helemaal niet/niet erg } \\
\text { verbonden } \\
\text { I = tamelijk/zeer verbon- } \\
\text { den } \\
\text { (weet niet = gecodeerd als } \\
\text { missend) }\end{array}$ \\
\hline $\begin{array}{l}\text { Leest betaalde natio- } \\
\text { nale krant }\end{array}$ & $\begin{array}{l}\text { 'Welk type krant leest u? Er zijn } \\
\text { meerdere antwoorden mogelijk' } \\
\text { (betaalde nationale krant) }\end{array}$ & $\begin{array}{l}0=\text { nee } \\
\mathrm{I}=\mathrm{ja}\end{array}$ \\
\hline $\begin{array}{l}\text { Leest betaalde lokale } \\
\text { krant }\end{array}$ & $\begin{array}{l}\text { 'Welk type krant leest u? Er zijn } \\
\text { meerdere antwoorden mogelijk' } \\
\text { (betaalde regionale of lokale krant) }\end{array}$ & $\begin{array}{l}0=\text { nee } \\
\mathrm{I}=\mathrm{ja}\end{array}$ \\
\hline
\end{tabular}


Tabel A (Vervolg)

\begin{tabular}{|c|c|c|}
\hline Variabelen & Vraag & Antwoordcategorieën \\
\hline $\begin{array}{l}\text { Participeert in } \\
\text { gemeente }\end{array}$ & 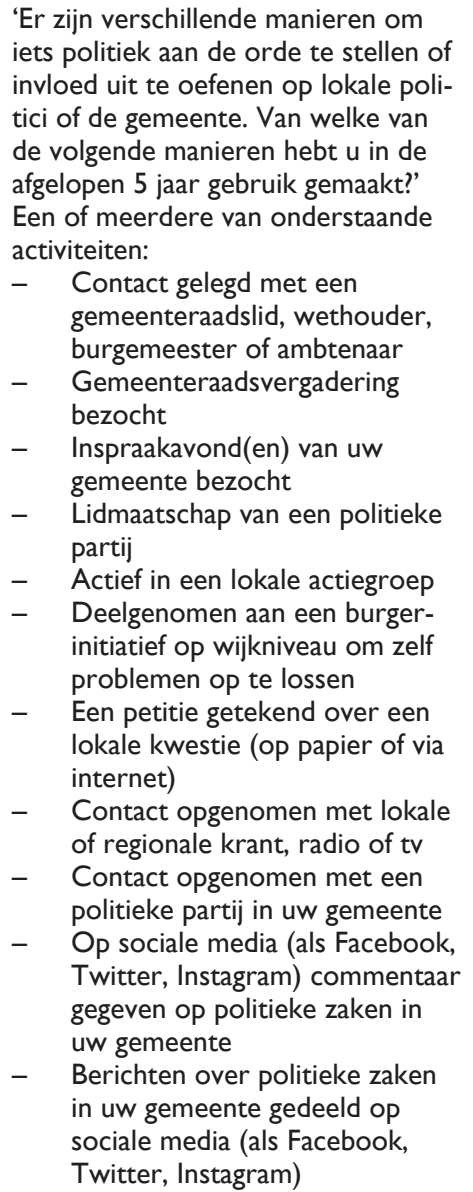 & $\begin{array}{l}0=\text { nee } \\
I=\text { ja }\end{array}$ \\
\hline
\end{tabular}

Politieke betrokkenheid

Weet wie burgemeester in gemeente is

Interesse nationale politiek

Interesse lokale politiek
'Weet u de naam van de burgemeester van uw gemeente?' (hercodering CentERdata)

'In hoeverre bent u geïnteresseerd in de nationale politiek?'

'In hoeverre bent u geïnteresseerd in de lokale politiek?'
$0=$ weet niet/incorrect antwoord/overig I = correct antwoord

$0=$ niet geïnteresseerd I = tamelijk/zeer geïnteresseerd

$0=$ niet geïnteresseerd I = tamelijk/zeer geïnteresseerd 
Tabel A (Vervolg)

\begin{tabular}{|c|c|c|}
\hline Variabelen & Vraag & Antwoordcategorieën \\
\hline $\begin{array}{l}\text { Vertrouwen nationale } \\
\text { politieke instituties }\end{array}$ & $\begin{array}{l}\text { 'Wilt u voor elk van de volgende } \\
\text { instellingen aangeven in hoeverre u } \\
\text { daar vertrouwen in hebt?' }\end{array}$ & $\begin{array}{l}\text { Opgestelde score van } \\
\text { Tweede Kamer en regering } \\
\text { (Spearman's rho }=.83 \text { ) } \\
\text { (I helemaal geen, } 2 \text { niet } \\
\text { zoveel, } 3 \text { tamelijk veel, } \\
4 \text { heel veel, weet niet }= \\
\text { gecodeerd als missend) }\end{array}$ \\
\hline $\begin{array}{l}\text { Vertrouwen gemeen- } \\
\text { telijke politieke institu- } \\
\text { ties }\end{array}$ & $\begin{array}{l}\text { 'Wilt u voor elk van de volgende } \\
\text { instellingen aangeven in hoeverre u } \\
\text { daar vertrouwen in hebt?' }\end{array}$ & $\begin{array}{l}\text { Opgestelde score van } \\
\text { gemeenteraad, College van } \\
\text { B\&W, gemeenteambtena- } \\
\text { ren en burgemeester } \\
\text { (Cronbach's alpha }=.9 \text { ) } \\
\text { (I helemaal geen, } 2 \text { niet } \\
\text { zoveel, } 3 \text { tamelijk veel, } \\
4 \text { heel veel, weet niet }= \\
\text { gecodeerd als missend) }\end{array}$ \\
\hline
\end{tabular}

